\title{
Leaf and Flower Extracts of Tithonia diversifolia Against Aphis go- sypii in Red Chili Plant
}

Toto Himawan, Tari Rahayu, Tita Widjayanti

Department of Plant Pest and Diseases, Faculty of Agriculture, University of Brawijaya Jl. Veteran, Malang 65145, East Java, Indonesiaa

Submitted 25 August 2020 Accepted 29 October 2020

Corresponding author Toto Himawan; totohimawan@yahoo.co.id

\section{ABSTRACT}

Red chili is one of the main commodities in Indonesia. Aphid (Aphis gossypii) is one of the pests that cause damage to the red chili plant. A. gossypii attacks require control measures using plant-based pesticides from the leaves and sunflowers of Mexico. This study aimed to determine the toxicity of leaves and flower of $T$. diversifolia extracts against $A$. gossypii. This research consisted of five concentrations $(0.1,0.3,0.5,0.7$ and $0.9 \%)$ and four replications. The $L_{50}$ and $L T_{50}$ were calculated by using probit analysis of the Hsin Chi program. The results showed that the Tithonia diversifolia flower extract had higher toxicity than the leaf extract of $0.48 \%$, which could cause the death of $A$. gossypii by $50 \%$, while the leaf extract had a concentration of $0.55 \%$. The flower extract caused the fastest $50 \%$ mortality ( 37.42 hours), while leaf extract was 65.63 hours. The leaf and flower extracts can also reduce the number of $A$. gossypii offspring.

Keywords: Tithonia diversifolia; Aphis gosypii; $\mathrm{LC}_{50}$; $\mathrm{LT}_{50}$; Aphid

\section{INTRODUCTION}

Red chili is one of Indonesia's primary commodities widely consumed on a household or industrial scale (Sativa et al., 2017). Insect pests can reduce crop yields and red chili plants (Chintkuntla, 2015). The pests that cause damage to the chili plants is Aphis gossypii (Chintkuntla, 2015). Aphis gossypii can cause direct damage to plants by sucking up fluid and taking sap from phloem tissue and cause changes in plant shape and decrease in plant vigor, which can reduce yield. Indirect damage includes the spread of honeydew and the transmission of the virus to host plants (Takalloozadeh, 2010). Because of the A. gossypii attack, control efforts are needed to minimize the damage of $A$. gossypii.

The adverse effects of chemical pesticides in controlling pests trigger pesticides made from nat- ural ingredients to control pests. Biopesticides that can be used are Mexican Sunflower (Tithonia diversifolia A. Gray) by utilizing the leaves and flowers. Chemical contents in these plants are alkaloids, saponins, tannins, terpenoid flavonoids, and phenols (Olayinka et al., 2015). This study aimed to investigate the toxicity of leaves and flower of $T$. diversifolia extracts against $A$. gossypii.

\section{MATERIALS AND METHODS}

\section{Red Chili Plant Preparation}

Red chili was planted in the seed tray until the plant was three weeks old. The planting media used were soil and compost (ratio of 1: 1). After three weeks old, the red chili was transplanted on an $18 \times 25 \mathrm{~cm}$ polybag media (soil, husk charcoal, 
study were red impala varieties. The plants were used in this study were 48 plants.

\section{Insects Test Rearing}

Aphis gossypii were obtained from infected red chili plants and were reared directly on the red chili plants used as treatment plants. Red chili plants were used as treatment aged 1.5 months. Each treatment was infested with10 A. gossypii. Infested plants with $A$. gossypii adults were covered with a plastic lid, and the top part was covered with gauze. Adults of A. gossypii were allowed to breed in the treatment plants to produce saplings in the form of $A$. gossypii nymphs. The adults were then transferred to the red chili plant, which was not used as a treatment plant, while the $A$. gossypii nymph was maintained on the treatment plant until six days old. The number of $A$. gossypii nymphs for each treatment was 20 adults $\left(4^{\text {th }}\right.$ instar).

Preparation of $T$. diversifolia Extraction Process

Leaves and flowers of $T$. diversifolia were washed and dried until slightly withered. Tithonia diversifolia leaves that had wilted were dried using an oven at $40^{\circ} \mathrm{C}$ for 2-3 days, while $T$. diversifolia flowers were dried for 1 day at the same temperature. Then, the dried leaves and flowers were ground using a grinder for 3 seconds and then macerated with a ratio of $1: 15$, which was 10 grams of material with $150 \mathrm{ml}$ of methanol. The sample was stirred using an orbital shaker for 24 hours. Then the filtrate was taken by filtering. The filtrate obtained was separated from the methanol solvent using a rotary vacuum evaporator at $65^{\circ} \mathrm{C}$. Application of $T$. diversifolia Leaf and Flower Extract

The application of $T$. diversifolia leaf and flower extract was carried out by spraying. The spray vol- ume used $10 \mathrm{ml}$ per plant. The volume was obtained from the calibration results. The leaves and flower extracts were then applied to the red chili plants used as treatment plants using a spray bottle. Extract treatment was sprayed using a sprayer and carried out in the morning when the stomata were open.

\section{Research Implementation}

The research was carried out consisted of 6 concentrations and four replications. The treatments consisted of controls $(0 \%), 0.1 \%, 0.3 \%$, $0.7 \%, 0.9 \%$ concentration. A concentration of $0.1 \%$ is obtained by taking $0.01 \mathrm{ml}$ solution from the main liquor and put it into a $10 \mathrm{ml}$ volumetric flask and $0.01 \mathrm{ml}$ solution was then added with distilled water, the solution was shaken until homogeneous, and the distilled water was added again to the limit mark of $10 \mathrm{ml}$.

\section{Data Analysis}

The data were analyzed using Analysis of Variance (ANOVA). If the test results were significantly different, further tests were conducted with the Duncan test of $5 \%$. The amount of toxicity $\left(\mathrm{LC}_{50}\right)$ and $\mathrm{LT}_{50}$ was calculated using the $\mathrm{Hsin}$ Chi probit analysis program. The mortality of $A$. gossypii was observed at $3,6,12,24$, and 48 hours after application. The percentage of mortality was calculated using the formula (Damayanti et al., 2013).

$$
\mathrm{M}=\frac{\sum \text { aphids death } \times 100 \%}{\sum \text { aphids were observed }}
$$

If there is a death in the control, then the $\%$ of deaths can be calculated using the Abbott formula ( $\%$ of deaths corrected), with the condition that the $\%$ of deaths is not more than $20 \%$. The formula is (Abbott, 1925): 


$$
P=X-Y / Y \times 100 \%
$$

Where: $P=$ Percentage of deaths corrected, $X=$ Percentage of insects that live in control, and $Y=$ Percentage of insects that live on treatment

The percentage reduction in the number of $A$. gossypii was calculated using the formula:

$\mathrm{P}=$ Number of offspring in control - number of offspring in treatment / Number of offspring in control

\section{RESULTS AND DISCUSSIONS}

\section{Mortality of A. gossypii}

The results showed that the highest mortality was found in the treatment concentration of $0.9 \%$ in both leaf and flower extract in 3 to 48 hours after application (Table 1). The percentage of mortality of $A$. gossypii due to the application of $T$. diversifolia leaf extract was $11.25,22.5,41.25,67.5$, and $100 \%$, respectively, while in the flower extract was $8.75,22.5,40,66.25$, and $100 \%$, respectively (Table 1). The application of Mexican sunflower leaf and flower extract at 48 hours after application showed the same percentage of $A$. gossypii mortality and showed no significant difference. It was presumably because both extracts contain almost the same active compound. According to (Olayinka et al., 2015), all parts of the T. diversifolia crop con- tained alkaloids, tannins, flavonoids, saponins, terpenoids, and phenols. Increased mortality of $A$. gossypii, both due to $T$. diversifolia leaves and flower extract concentrations were thought to be caused by compounds in leaf and flower extracts that function as stomach poisons. The stomach poison causes the test insect not to die immediately but causes the test insect to die slowly (Alkan et al., 2017). Toxins entered are then absorbed by the digestive tract and eventually lead to death (Dawson, J. E., \& Strang, 2000).

\section{$L_{50}$ of $T$. diversifolia Leaf and Flower Extract against $A$. gossypii}

The results showed that the $\mathrm{LC}_{50}$ value of $T$. diversifolia leaf extract in $0.55 \%$ concentration (5500 ppm) could cause $50 \%$ mortality of $A$. gossypii, while the flower extract was $0.48 \%$ (4800 ppm). The $\mathrm{LC}_{90}$ value of $T$. diversifolia leaf extract in $0.99 \%$ concentration (9900 ppm) can cause $90 \%$ mortality of $A$. gossypii, while the flower extract was $1.08 \%$ (10800 ppm) (Table 2). The chemical compounds in $T$. diversifolia flowers have the highest concentration of $\alpha$ - Pinene until $34.42 \%$ (Oludare et al., 2016). That was caused by the content of secondary metabolites collected in many parts of the flower. Secondary metabolites that have been produced by plants will be stored in the main storage

Table 1. Mortality Rate A. gossypii Due to the Application of $T$. diversifolia Leaf and Flower Extracts

\begin{tabular}{lccccc}
\hline & \multicolumn{5}{c}{ Mortality of $\boldsymbol{A}$. gossypii (\%) } \\
\cline { 2 - 6 } Plant Extract & 3 HAA & 6 HAA & 12 HAA & 24 HAA & 48 HAA \\
\hline 0.1\% Leaf & $0 \mathrm{a}$ & $0 \mathrm{a}$ & $0 \mathrm{a}$ & $1.25 \mathrm{a}$ & $6.25 \mathrm{a}$ \\
0.1\% Flower & $0 \mathrm{a}$ & $0 \mathrm{a}$ & $0 \mathrm{a}$ & $3.75 \mathrm{a}$ & $12.5 \mathrm{a}$ \\
$0.3 \%$ Leaf & $0 \mathrm{a}$ & $2.5 \mathrm{ab}$ & $6.25 \mathrm{~b}$ & $12.5 \mathrm{~b}$ & $22.5 \mathrm{~b}$ \\
0.3\% Flower & $0 \mathrm{a}$ & $2.5 \mathrm{ab}$ & $6.25 \mathrm{~b}$ & $15 \mathrm{bc}$ & $27.5 \mathrm{~b}$ \\
0.5\% Leaf & $0 \mathrm{a}$ & $6.25 \mathrm{bc}$ & $13.75 \mathrm{c}$ & $25 \mathrm{~cd}$ & $42.5 \mathrm{c}$ \\
0.5\% Flower & $2.5 \mathrm{~b}$ & $11.25 \mathrm{e}$ & $21.25 \mathrm{~d}$ & $36.25 \mathrm{de}$ & $60 \mathrm{~d}$ \\
0.7\% Leaf & $0 \mathrm{a}$ & $10 \mathrm{de}$ & $22.5 \mathrm{~cd}$ & $41.25 \mathrm{e}$ & $70 \mathrm{~d}$ \\
0.7\% Flower & $2.5 \mathrm{~b}$ & $11.25 \mathrm{e}$ & $25 \mathrm{~d}$ & $41.25 \mathrm{e}$ & $65 \mathrm{~d}$ \\
0.9\% Leaf & $11.25 \mathrm{c}$ & $22.5 \mathrm{f}$ & $41.25 \mathrm{e}$ & $67.5 \mathrm{f}$ & $100 \mathrm{e}$ \\
$0.9 \%$ Flower & $8.75 \mathrm{c}$ & $22.5 \mathrm{f}$ & $40 \mathrm{e}$ & $66.25 \mathrm{f}$ & $100 \mathrm{e}$ \\
\hline
\end{tabular}

Note: Numbers followed by the same letter in the same column are not significantly different at the Duncan test level of $5 \%$, and HAA is hours after application 
area, namely in flowers and seeds (Taiz and Zeiger, 2002). Phytochemical analysis results of $T$. diversifolia leaf and flower extract, paitan leaf extract contains 106 types of compounds, while paitan flower extract contains 48 types of compounds. Based on the results of the phytochemical analysis, it was found that the extract of the leaves and paitan flowers had the highest content of compounds in the form of hexadecanoic acid and linoleic acid. The highest content of hexadecanoic acid and linoleic acid is found in $T$. diversifolia flower extract. The content of hexadecanoic acid in $T$. diversifolia flower extract was $12.08 \%$, while $T$. diversifolia leaf extract was $12.06 \%$. The content of linoleic acid in T. diversifolia flower extract was $20.40 \%$, while $T$. diversifolia leaf extract was $10.83 \%$. Linoleic acid can cause inhibition of the feeding ability of test insects (Khani et al., 2011). Toxic compounds that enter the body of insects through the body's natural hole is the cuticle. Compounds that have entered the insect's body will spread carried by the blood circulation and attack the insect's nervous system so that over time will cause death (James and Xu, 2011). Compounds that can inhibit the ability to eat insects cause insects to stop eating and then cause hunger.

\section{$\mathrm{LT}_{50}$ of T. diversifolia Leaf and Flower Extract}

The results showed that the $\mathrm{LT}_{50}$ value of $T$. diversifolia leaf extract was 65.63 hours, while $T$. diversifolia flower was 37.42 hours. $\mathrm{LT}_{90}$ value of $T$. diversifolia leaf extract obtained as a concentration that caused death in $A$. gossypii by $90 \%$ was 477.24 hours, while $T$. diversifolia flower extract was 201.64 hours. The T. diversifolia leaf extract regression equation's value shows that each time multiple will cause $A$. gossypii death by $1.487 \%$, while the $T$. diversifolia flower extract was $1.752 \%$ (Table 3).

Mexican sunflower leaf extract was slower to cause $A$. gossypii mortality caused by the low content of chemical compounds. Jumepaeng et al. (2013) reported that citronella leaf has a low polarity level. The low mortality of the test insects was due to the low content of the active compounds leaves compared to $T$. diversifolia flowers (Moronkola et al., 2007).

\section{Effect of Leaves and Flower Extract on The} Number of Pupae and Adults of A. gossypii

Tithonia diversifolia leaf and flower extracts were effects on reducing the number of offspring produced by $A$. gossypii. The emergence of $A$. gossypii offspring was marked by the presence of new individuals in the form of $A$. gossypii nymphs. The nymph $A$. gossypii has a smaller size and brighter color than the imago A. gossypii (Figure 1). The leaf and flower extract can cause a decrease the number of $A$. gossypii offspring with the highest percentage reduction in the number of offspring found in $T$. diversifolia flower extract, but the results show no significant difference between leaf and flower extract. The highest percentage decline in the number of offspring was found at a concentration of $0.9 \%$ both in the treatment with leaf ex-

Table 2. $\mathrm{LC}_{50}$ value of $T$. diversifolia Leaf and Flower Extracts

\begin{tabular}{llccccc}
\multirow{2}{*}{ Plant Extract } & \multirow{2}{*}{ Regression } & SE & LC $_{50}$ & LC $_{90}$ & \multicolumn{2}{c}{ limit value of LC $\mathbf{5}_{\mathbf{5 0}}$} \\
\cline { 5 - 7 } & & & & & Bottom & Up \\
\hline Leaf & $\mathrm{y}=11.630 \mathrm{x}+2.791$ & 1.513 & 0.55 & 0.99 & 1.499 & 1.609 \\
Flower & $\mathrm{y}=8.716 \mathrm{x}+3.504$ & 1.145 & 0.48 & 1.08 & 1.307 & 1.911 \\
\hline
\end{tabular}


Table 3. $\mathrm{LT}_{50}$ value of $T$. diversifolia Leaf and Flower Extracts

\begin{tabular}{|c|c|c|c|c|c|c|}
\hline \multirow{2}{*}{ Plant Extract } & \multirow{2}{*}{ Regression } & \multirow{2}{*}{ SE } & \multirow{2}{*}{$\mathrm{LT}_{50}$} & \multirow{2}{*}{$\mathrm{LT}_{90}$} & \multicolumn{2}{|c|}{$\begin{array}{l}\text { Limit value of } \\
\qquad T_{50}\end{array}$} \\
\hline & & & & & Bottom & Up \\
\hline $\begin{array}{l}\text { Leaf } \\
\text { Flower }\end{array}$ & $\begin{array}{l}y=1.487 x+2.297 \\
y=1.752 x+2.244\end{array}$ & $\begin{array}{l}0.262 \\
0.269\end{array}$ & $\begin{array}{l}65.63 \\
37.42\end{array}$ & $\begin{array}{l}477.24 \\
201.64\end{array}$ & $\begin{array}{l}57.716 \\
30.889\end{array}$ & $\begin{array}{l}76.495 \\
48.528\end{array}$ \\
\hline
\end{tabular}

tract was $76.01 \%$, and flower extract was $77.5 \%$ (Table 4).

The decrease in the number of offspring produced by $A$. gossypii was caused by residue active in $A$. gossypii. These residues can affect the metabolism of nutrients needed to support the development and reproduction of insects. The inhibiting process of insects' growth and development has a relationship with insect growth regulators (IGR) that work on the endocrine system or insect hormones. Most IGRs enter the insect's body and mimic the juvenile hormone produced in the insect's brain. The juvenile hormone then provides insects with information to remain in the immature or mature phase. When insects are sufficient to experience growth, juvenile hormones' production stops to make skin turnover into the adult phase (Valles and Koehler, 2014). Interference with the production of one type of hormone can inhibit cellular respiration in hormone-producing organs and will affect the overall functioning of the hormone system. It causes insects to face obstacles in their growth (Chapman, 1998).
The active ingredient is alleged to affect the number of offspring of $A$. gossypii. The odor contained in $T$. diversifolia flower extract comes from flavonoids. The flavonoids play an essential role in plants' color and aroma (Panche et al., 2016). Meanwhile, essential oils can inhibit the eating power of insects (Jalali sendi and Ebadollahi, 2013). Food inhibiting activities can influence the insect development process to reduce the utilization of nutrients for insect growth and reproduction activities. The decrease in the number of $A$. gossypii offspring due to the application of $T$. diversifolia flower extract shows that $T$. diversifolia flower is effective in influencing the number of $A$. gossypii offspring.

\section{CONCLUSIONS}

Tithonia diversifolia flower extract had higher toxicity than leaf extract in $0.48 \%$ concentration and can cause $50 \%$ mortality of $A$. gossypii, while leaf extract in $0.55 \%$. The flower extract can cause the fastest $50 \%$ mortality ( 37.42 hours), while leaf extract was 65.63 hours. Furthermore, the extracts

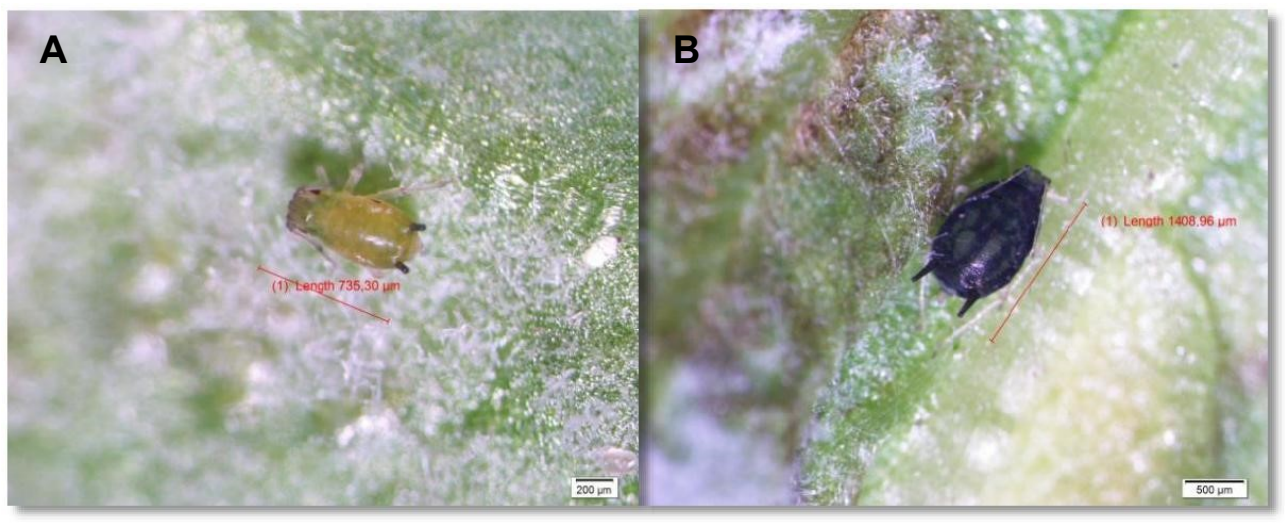

Figure 1. Aphis gossypii A. Nymphs and B. Adults 
Table 4. Percent reduction of the number of offspring after application

\begin{tabular}{ccc}
\hline Concentration & Leaf extract (\%) & Flower extract (\%) \\
\hline $0.10 \%$ & $17.77 \mathrm{a}$ & $23.42 \mathrm{ab}$ \\
$0.30 \%$ & $29.46 \mathrm{ab}$ & $36.38 \mathrm{bc}$ \\
$0.50 \%$ & $47.64 \mathrm{~cd}$ & $51.25 \mathrm{de}$ \\
$0.70 \%$ & $61.85 \mathrm{e}$ & $62.60 \mathrm{ef}$ \\
$0.90 \%$ & 76.01 & $77.50 \mathrm{f}$ \\
\hline
\end{tabular}

of leaf and flower might cause the number of A.gossypii's offspring to decrease.

\section{REFERENCES}

Abbott, W.S. 1925. A Method of Computing the Effectiveness of an Insecticide. J. Econ. Entomol. 18(2): 265-267. doi: 10.1093/ jee/18.2.265a.

Alkan, M., A. Gokce, and K. Kara. 2017. Stomach poison activity of some plant extracts on Colorado potato beetle (Coleoptera: Chrysomelidae). Plant Prot. Bull. 57: 305-315. doi: 10.16955/bitkorb.297213.

Chapman, R.F. 1998. images (S.. Simpson and A.E. Douglas, editors). Fifth Edit. Cambridge University Press, New York.

Chintkuntla. 2015. Maize as a barrier crop in reducing aphids, the virus vector of chilli. Mardi Res. J. 19(2): 251-258.

Damayanti, R.R., T. Himawan, and L.P. Astuti. 2013. 17 Penghambatan Reproduksi Rhyzopertha dominica F. (Coleoptera: Bostrichidae) Menggunakan Fumigan Tablet Berbasis Minyak Mimba. 1(September): 17-26.

Dawson, J. E., and Strang, T.J.K. 2000. Solving museum insect problems : chemical control.

Jalali sendi, J., and A. Ebadollahi. 2013. Biological Activities of Essential Oils on Insects. p. 129150

James, R.R., and J. Xu. 2011. Mechanisms by which pesticides affect insect immunity. J. In- vertebr. Pathol. 109: 175-182. doi: 10.1016/ j.jip.2011.12.005.

Jumepaeng, T., R. Jantayota, S. Hemmood, S. Komolwanich, S. Wuthisarn, et al. 2013. Determination and Comparison of Volatile Aroma Compounds in Fresh and Dried Leaves Samples of Citronella Grass, Lemongrass, and Citronella Incense Products by MicroHydrodistillation. Acta Chromatogr. 26. doi: 10.1556/AChrom.26.2014.1.13.

Khani, M., R.M. Awang, D. Omar, M. Rahmani, and S. Rezazadeh. 2011. Tropical medicinal plant extracts against rice weevil, Sitophilus oryzae L. J. Med. Plants Res. 5(2): 259-265.

Moronkola, D., I. Ogunwande, T. Walker, W. Setzer, and I. Oyewole. 2007. Identification of the main volatile compounds in the leaf and flower of Tithonia diversifolia (Hemsl) Gray. J. Nat. Med. 61: 63-66. doi: 10.1007/s11418006-0019-5.

Olayinka, B.U., D.A. Raiyemo, and E.O. Etereje. 2015. Phytochemical and Proximate Composition of Tithonia diversifolia ( Hemls .) A . Gray, a perennial broad-leaved weed species reported ornamental plant (Akobundu and Agyakwa, Sc. Ann. Food Sci. Technol. 16(1).

Oludare, A., S. Oyedeji, and A. Ayokun-nun. 2016. Chemical composition and antimicrobial activities of essential oil extracted from Tithonia diversifolia (Asteraceae) flower. J. Bioresour. Bioprod. 1: 169-176. 
Panche, A.N., A.D. Diwan, and S.R. Chandra. 2016. Flavonoids: An overview. J. Nutr. Sci. 5. doi: 10.1017/jns.2016.41.

Sativa, M., H. Harianto, and A. Suryana. 2017. Impact of Red Chilli Reference Price Policy in Indonesia. Int. J. Agric. Syst. 5: 120. doi: 10.20956/ijas.v5i2.1201.

Taiz, L., and E. Zeiger. 2002. download. Third Edit. Sinauer Associates, Sunderland.

Valles, S.M., and P.G. Koehler. 2014. Insecticides Used in the Urban Environment: Mode of Action. Pests around South. Home: 1-4. 